\title{
WATER AND WASTEWATER DISINFECTION BY ULTRASOUND IRRADIATION- A CRITICAL REVIEW
}

\author{
NADDEO $\mathrm{V}_{.}^{1,{ }^{*}}$ \\ CESARO A. ${ }^{1}$ \\ MANTZAVINOS D. ${ }^{2}$ \\ FATTA-KASSINOS D. ${ }^{3}$ \\ BELGIORNO $\mathbf{~}^{1}$
}

\author{
${ }^{1}$ University of Salerno, Department of Civil Engineering \\ Sanitary Environmental Engineering Division (SEED) \\ Via Giovanni Paolo II, 132, 84084 Fisciano, Italy \\ ${ }^{2}$ University of Patras, Department of Chemical Engineering \\ Caratheodory 1, University Campus, GR-26504 Patras, Greece \\ ${ }^{3}$ Nireas-International Water Research Center \\ School of Engineering, University of Cyprus \\ PO Box 20537, 1678 Nicosia, Cyprus
}

Received: 29/01/14

Accepted: 23/06/14

Available online: 29/07/2014 *to whom all correspondence should be addressed e-mail: vnaddeo@unisa.it

\section{ABSTRACT}

It is well known that chlorine and its compounds, traditionally utilized for water and wastewater disinfection, react with some organic matter to form undesirable by-products, hazardous to human health, known as Disinfection By-Products (DBPs). In many countries very stringent limits for chlorination by-products such as trihalomethanes were set for wastewater reuse. Accordingly, the use of different oxidation/disinfection systems should be evaluated as possible alternative to chlorine. Ultrasound (US) was recently found to be effective for this purpose.

Aim of this work is to review main US disinfection studies, pointing out ultrasound mechanisms as well as its effects in terms of different bacteria inactivation (Total coliform, Escherichia coli, Pseudomonas aeruginosa, Bacillus subtilis, Saccharomyces cerevisiae, Klebsiella pneumonia) at both laboratory scale and pilot-scale. To this end, several experimental results were discussed and both focal interest points and encountered problems were summarized.

Moreover the intensification of cavitation phenomena by combined oxidation processes was overviewed and main advantages and disadvantages were pointed out, in order to address future research and promote efficient large scale operations.

Keywords: cavitation, combined treatments, Escherichia Coli, frequency, microorganisms inactivation, pathogen, removal, sonication.

\section{Introduction}

Disinfection process is a conventional step used to remove pathogen microorganisms from both drinking water and wastewater, in order to eliminate waterborne microbiological contamination caused by pathogenic bacteria, viruses and protozoan parasites and protect public health as well as the environment.

Disinfection agents commonly used within both drinking water and wastewater treatment plants are chlorine and its related compounds, such as sodium and calcium hypochlorite and chlorine dioxide, with chlorine being by far the most widely used disinfectant (Winward et al., 2008). The strong oxidizing 
potential of these reagents provides a minimum level of chlorine residual throughout the distribution system and adequate protection against microbial recontamination (Sadiq et al., 2004).

However, in the early 1970s, it was found that chlorine reacts with the natural organic matter present in water and wastewater to produce various undesirable chlorinated disinfection by-products (DBPs). Among these, trihalomethanes (THMs) and haloacetic acids are the most dangerous by-products for public health since they are considered to be potentially carcinogenic and/or mutagenic (Rook, 1974). Therefore, the use of chlorine compounds as disinfectant in water and wastewater treatment requires the dechlorination of the effluent to minimize the potential toxic effects of low level chlorine residuals as well as to prevent the formation of DBPs in receiving water bodies.

This disadvantage has emphasized the need for exploring alternative disinfectants and new treatment technologies (Gopal et al., 2007). In this respect, ozonation and UV-C irradiation have traditionally been tested and, to a certain extent, employed as disinfection methods due to the simplicity of operation and the relatively affordable operating and maintenance costs (Rice et al., 1981; Symons et al., 1989; Lin et al., 1999; Bonacquisti, 2006; Wait et al., 2007). In recent years research on disinfection has been directed to the use of (i) $\mathrm{TiO}_{2}$ heterogeneous photocatalysis driven by artificial (UV or visible) or natural sunlight irradiation (Fernández et al., 2005; Belgiorno et al., 2007), and (ii) ultrasound (US) which represents a relatively innovative technique to conventional treatment technologies (Mason and Tiehm, 2001; Khan et al., 2006; Naddeo et al., 2007).

The science of ultrasound involves the study of the formation, impact and applications of sonorous waves occurring at frequencies higher than $20 \mathrm{kHz}$, which represents the upper audibility threshold of the human ear.

Ultrasound has been studied with reference to physical (Mason, 1976; Hoyler and Luke, 1984; Asher, 1987), chemical (Richards and Loomis, 1927; Flisak and Perna, 1977; Suslick and Doktycz, 1990; Thomas and De Vries, 1959; Srinivasan et al., 1995), medical (Dunn, 1991; Byrne, 1984; Kulier and Kapp, 2011), industrial and environmental engineering applications (Brown and Goodman, 1965; Thakore, 1990; Hunicke, 1990; Floros and Liang, 1994; Ince et al., 2001; Mason, 2007). The latter include (i) the degradation and removal of conventional and emerging contaminants in wastewaters (Naddeo et al., 2007, Hoffman et al., 1996; Lifka et al., 2003; Gogate, 2008; Naddeo et al., 2009a; Naddeo et al., 2009b; Naddeo et al., 2010; Mendez-Arriaga et al., 2008; Secondes et al., 2014), (ii) drinking water and wastewater disinfection (Harvey and Loomis, 1929; Mason et al., 2003; Naddeo et al., 2009c; Arrojo et al., 2008), (iii) sludge (Tiehm et al., 1997; Chu and Lee, 2004; Wang et al., 2005; Bougrier et al., 2005; Climent et al., 2007; Naddeo et al., 2009d) and solid waste (Chen et al., 2008; Cesaro et al., 2012; Cesaro and Belgiorno, 2013; Cesaro et al., 2014) treatment prior to anaerobic digestion, (iv) landfill leachate pre-treatment (Lema et al., 1998; Gonze et al., 2003; Neczaj et al., 2007), (v) extraction of substances from contaminated sediments (Mecozzi et al., 2002; Collasiol et al., 2004; Moreda et al., 2004) and (vi) air purification (Grinthal and Ondrey, 1992; Serpone et al., 1994).

The use of ultrasound for disinfection purposes has been extensively studied. This paper aims at reviewing main studies on the topic, thus pointing out action mechanisms of ultrasound and its efficiency as well as the variation in the process performance occurring after the combination of ultrasound with other oxidation processes.

Main advantages and drawbacks are also highlighted, in order to address future research and promote efficient large scale operations.

\section{Disinfection mechanisms and reaction systems during ultrasound irradiation}

The first report on the use of ultrasound as disinfectant was published by Harvey and Loomis (1929) in the late 1920s. In their pioneering work, authors reported the positive disinfectant action of ultrasound, pointing out that the process could not be considered of any practical or commercial importance due to its expense. 
In early to mid 1970s, three other reports (Burgos et al., 1972; Burleson et al., 1975; Dahl, 1976) discussed the likely use of ultrasound as a disinfection agent due to its ability to decrease the heat resistance of bacterial spores (Burgos, 1972) or to act synergistically to ozone-induced disinfection of viruses and bacteria (Burleson et al., 1975; Dahl, 1976).

Nowadays, it is well-documented that ultrasound disinfection power is related to the occurrence of cavitation phenomena (Mason and Peters, 2002). It consists of the production of micro-bubbles, which are generated when a great negative pressure is applied to a liquid (Mason and Peters, 2002). Compression and rarefaction waves rapidly move through the liquid media. If the waves are sufficiently intense they will break the attractive forces in the existing molecules and create gas bubbles. As ultrasound energy enters the liquid, the gas bubbles grow until they reach a critical size beyond which they either implode or collapse, thus releasing a great energy amount and promoting sonochemical reactions (Neppiras, 1980; Dehghani, 2005). In a cavitating liquid these reactions occur in three regions (Figure 1): the gas bubble; the interface between the gas phase and the liquid bulk; the liquid bulk itself (El' Piner, 1964).

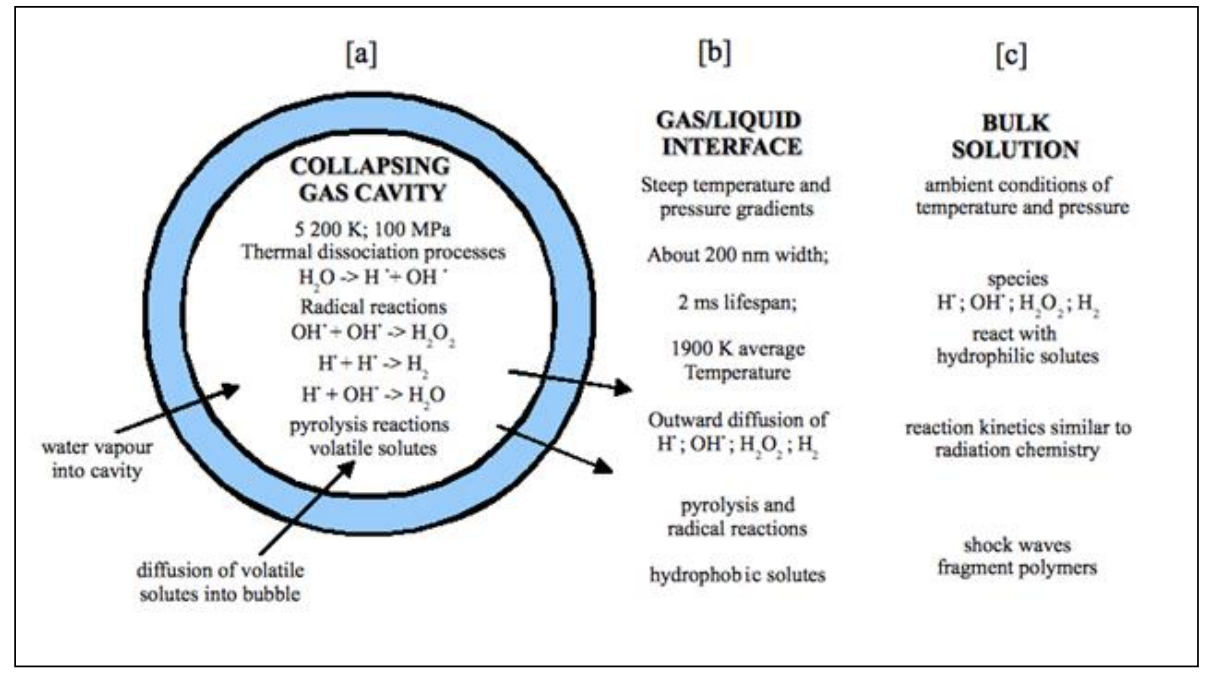

Figure 1. Schematic diagram of the regions in a cavitating liquid where chemical reactions take place

According to the "hot-spot theory", cavitational bubble collapse produces an intense increase in temperature, up to $5000 \mathrm{~K}$, as well as in pressure, thus promoting the formation of free radicals (e.g., $\cdot \mathrm{OH}, \mathrm{HO}_{2}{ }^{\bullet}$ and $\mathrm{O} \bullet$ ) (Furuta et al., 2004), with a strong oxidative power. Both physical and chemical effects are, therefore, promoted by cavitation: it has been extensively proved that physical phenomena are predominant at low frequency, while high frequency ultrasound mainly supports chemical effects (Carrére et al., 2010).

Therefore, a number of physical, mechanical and chemical processes arise from acoustic cavitation, which can inactivate bacteria and de-agglomerate bacterial clusters (Furuta et al., 2004; von Sonntag, 1986; Oyane et al., 2009; Joyce et al., 2003a). These effects include:

- pressures and pressure gradients resulting from the collapse of gas bubbles, which enter the bacterial solution on or near the bacterial cell wall. Bacterial cell damage results from mechanical fatigue over a period of time, which depends on frequency;

- shear forces induced by micro-streaming occurring within bacterial cells;

- chemical oxidation by free radicals $(\bullet \mathrm{OH}$ and $\bullet \mathrm{H})$ during cavitation in the aqueous medium. These radicals attack the chemical structure of the bacterial cell wall and weaken the cell wall to the point of disintegration.

As a result, disinfection processes rely on two main phenomena occurring due to acoustic cavitation effects. 
The first is bacterial splitting which breaks up bacterial agglomerates into a greater number of individual bacteria in a suspension. The second is bacterial killing (or inactivation) which results in less individual reproduction ability of bacteria being present in a suspension. The overall effect of applying ultrasound is thus the result of a competition between splitting and inactivation of bacteria in solution. For this reason disinfection efficiency is strongly influenced by both irradiation time and intensity as well as from the reactor configuration.

Several types of reaction systems (Figure 2) have been employed for ultrasound-induced disinfection studies, as reported in several papers (Reisse et al., 1999; Gogate and Pandit, 2004; Gogate, 2007). In brief, the ultrasonic probe is suitable to treat relatively small volumes of liquid with the ultrasound irradiation being localized around the emitting horn and not distributed as in the case of ultrasonic bath, plug-flow reactor and the flow cell. The plug-flow reactor consists of immersed ultrasound transducers unlike the bath, where the transducers are not in direct contact with the liquid phase; moreover, it can treat larger volumes than the probe or the bath. On the other hand, the flow cell is a unique system that works under pressure and the water inside is sonicated all around.

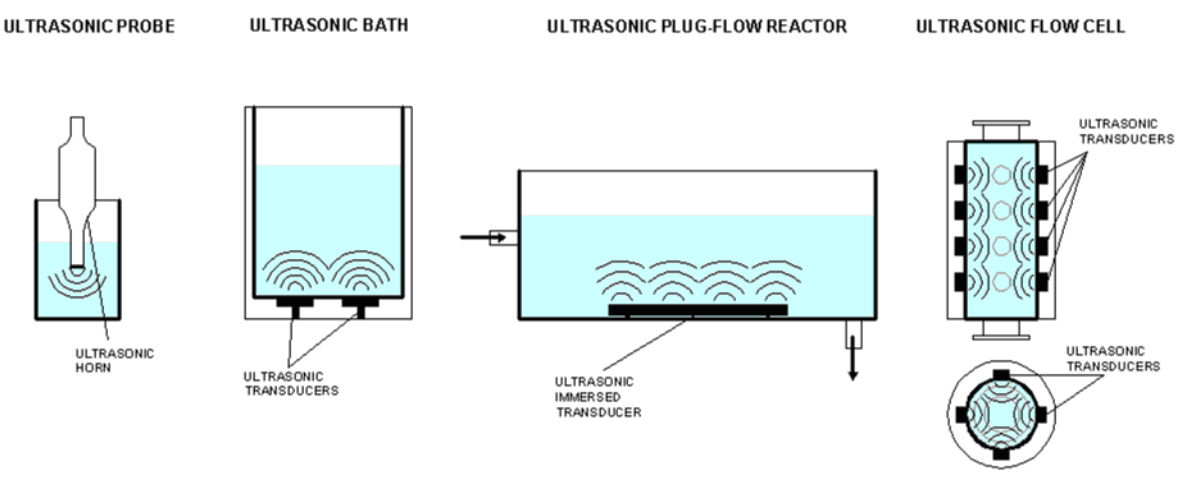

Figure 2. Ultrasonic systems typically used for sonochemical treatment

The following paragraphs overview several studies on the use of ultrasound, either alone or in combination with other advanced oxidation processes, to treat several types of microorganisms in different aqueous matrices.

\section{Disinfection by ultrasound irradiation}

Table 1 summarizes studies on the inactivation of various microorganisms induced by ultrasound irradiation as the sole disinfectant; relevant operating conditions and efficiencies are quoted.

Most studies focus on the inactivation of Escherichia coli in various aqueous matrices, mainly synthetic ones. The interest in this kind of microorganism is reasonably related to the evidence that it is one the most used faecal contamination indicator in Regulations and guidelines dealing with water and wastewater quality assessment.

E. coli inactivation exhibited pseudo-first order behaviour and its extent was found to enhance with increasing intensity: Hua and Thompson (2000) investigated the effect of ultrasound density in the range $270-460 \mathrm{~W} \mathrm{I}^{-1}$ at a frequency of $20 \mathrm{kHz}$ and they observed that the extent of $E$. coli inactivation became about $2.8 \mathrm{Log}$ after $60 \mathrm{~min}$ at the highest density of $460 \mathrm{~W} \mathrm{I}^{-1}$.

Similarly, Antoniadis et al., (2007), performed experiments at laboratory scale, using both synthetic municipal and septic tank wastewaters, in order to verify US effects on $E$. coli inactivation. In both cases, $100 \mathrm{ml}$ of wastewater were subjected to ultrasonic irradiation by a device operating at a fixed frequency of $80 \mathrm{kHz}$ and a variable electric power output up to $150 \mathrm{~W}$, connected to a titanium-made horn with a 7 $\mathrm{mm}$ tip. For those experiments carried out at a frequency of $24 \mathrm{kHz}$, a horn-type sonicator operating at a variable electric power output up to $450 \mathrm{~W}$ was used instead. 
It was observed that high power and low frequency ultrasound is capable of eliminating nearly completely the $E$. coli colonies in synthetic municipal wastewaters as well as the total microbiological load in actual municipal wastewaters at relatively short irradiation times.

Furuta et al., (2004), investigated the inactivation of $E$. coli along with hydrogen peroxide formation due to water sonolysis, in order to assess the feasibility of hydrogen peroxide formation as an indicator of bacterial inactivation. A $27.5 \mathrm{kHz}$ horn type sonicator was used; its operation was based on the "squeeze-film effect" (i.e. the film is defined as the space between the end of the probe of the sonicator and the bottom of the reactor) and the maximum power of this sonicator was $42 \mathrm{~W} \mathrm{ml}^{-1}$. When the amplitude on the vibration face was $3 \mathrm{~mm}$, inactivation was 6 Log at room temperature. They observed that the ultrasonic shock wave was more important in killing microorganisms than the indirect effect of - $\mathrm{OH}$ radicals formed by ultrasonic cavitation. Ultrasound waves at a frequency of $42 \mathrm{kHz}$ were also used to treat aqueous suspensions of $E$. coli in the study by Dehghani, (2005); the author reported a 2.7 Log inactivation at a power density of $120 \mathrm{~W} \mathrm{I}^{-1}$ and a sonication time of $90 \mathrm{~min}$.

In most of the reviewed studies, authors used low frequencies systems, which allow the achievement of the best performances in terms of microorganisms inactivation in comparison to high frequency ultrasonic technologies. Joyce et al. (2003a) studied the effects of sonication on Bacillus subtilis inactivation at different frequencies and found that both 20 and $38 \mathrm{kHz}$ did not determine dramatic effect on the viability of the bacteria. Conversely, over the first $5 \mathrm{~min}$, the higher frequencies produce an immediate rise in the concentration of microorganisms expressed as CFU (Colony-Forming Unit). Then a steady fall was observed but the level remains above the original concentration even after 15 min sonication.

These results suggest that the major effect of high frequency ultrasound is the declumping of bacterial agglomerates with little deactivation, while low frequency ultrasound, at higher powers, are characterized by a substantially higher kill rate.

Ultrasound has also been used in combination with other advanced oxidation processes. In the following paragraphs main combinations are pointed out, in order to highlight advantages and drawbacks.

\section{Disinfection by ultrasound irradiation coupled to other processes}

Although sonication can provide powerful disinfection, it is an energy-consuming system. In order to reduce US energy input, great interest has been directed towards the coupling of this technology with other processes, such as $\mathrm{TiO}_{2}$ photocatalysis, UV irradiation, electrolysis and ozonation or other disinfectants such as sodium hypochlorite and hydrogen peroxide.

Table 2 summarizes studies on the inactivation of various microorganisms induced by ultrasound irradiation coupled to another process or disinfectant; relevant operating conditions and efficiencies are quoted.

\subsection{Ultrasound and electrolysis disinfection efficiency}

Among the studies dealing with ultrasound and electrolysis coupling, Joyce et $a_{._{L}}$ (2003b), investigated the efficiency of the combined process as a disinfection treatment to inactivate Klebsiella pneumonia. Experiments were conducted in a temperature-controlled ultrasonic bath (at a frequency of $40 \mathrm{kHz}$ ), with the electrodes immersed in the liquid phase. The electrode materials were carbon (felt and graphite), copper and stainless steel rods. It was found that the combined treatment was more efficient than ultrasound irradiation or electrolysis applied individually.

Disinfection happens as an effect of metal ions impacting microbial cells or through the generation of hydrogen peroxide, hydroxyl radicals and hypochlorous acid. At a frequency of $40 \mathrm{kHz}$ and a density of $50 \mathrm{~W}^{-1}$, the inactivation of Klebsiella pneumonia was $50 \%$ after $2 \mathrm{~min}$ sonication and it proved to be complete after $5 \mathrm{~min}$. 
Table 1. Efficiency of various microorganisms inactivation by ultrasound irradiation only.

\begin{tabular}{|c|c|c|c|c|c|c|c|}
\hline Microorganism & $\begin{array}{l}\text { Aqueous } \\
\text { mean }\end{array}$ & $\begin{array}{l}\text { Ultrasonic } \\
\text { system }\end{array}$ & $\begin{array}{l}\text { Frequency } \\
\quad[\mathrm{kHz}]\end{array}$ & $\begin{array}{l}\text { Density } \\
{\left[\mathrm{W} \mathrm{I}^{-1}\right]}\end{array}$ & $\begin{array}{l}\text { Maximum } \\
\text { sonication } \\
\text { time [min] }\end{array}$ & Work highlights & Reference \\
\hline \multirow{3}{*}{ Bacillus subtilis } & \multirow{3}{*}{$\begin{array}{l}\text { Synthetic } \\
\text { solution }\end{array}$} & Bath & 38 & 180 & & \multirow{3}{*}{$\begin{array}{c}\text { Although US proved to be effective in bacteria } \\
\text { declumping, the kill rate of low frequency high } \\
\text { power systems is substantially higher }\end{array}$} & \multirow{3}{*}{ Joyce et al., 2003a } \\
\hline & & Probe & 20 & 240 & 15 & & \\
\hline & & & 512 and 850 & 71 or 64 & & & \\
\hline \multirow{4}{*}{ Escherichia coli } & $\begin{array}{l}\text { Synthetic } \\
\text { solution }\end{array}$ & Probe & 20 & 270 & 60 & $\begin{array}{l}\text { E. Coli inactivation exhibits depends moderately on } \\
\text { total power and power intensity at low frequency }\end{array}$ & $\begin{array}{l}\text { Hua and Thompson, } \\
2000\end{array}$ \\
\hline & $\begin{array}{l}\text { Synthetic } \\
\text { solution }\end{array}$ & Probe & 27.5 & 42 & 3 & $\begin{array}{l}\text { Inactivation rate gradually increased with } \\
\text { increasing amplitude of the vibration face }\end{array}$ & Furuta et al., 2004 \\
\hline & $\begin{array}{l}\text { Aqueous } \\
\text { suspension }\end{array}$ & Bath & 42 & 0.12 & 90 & Low frequency US effective in E. Coli inactivation & Dehghani, 2005 \\
\hline & $\begin{array}{c}\text { Synthetic } \\
\text { municipal } \\
\text { and septic } \\
\text { tank } \\
\text { wastewaters }\end{array}$ & Probe & 24 and 80 & $1500-4500$ & 120 & $\begin{array}{l}\text { Ultrasound provided a permanent elimination of } \\
\text { cells }\end{array}$ & Antoniadis et al., 2007 \\
\hline $\begin{array}{l}\text { Saccharomyces } \\
\text { cerevisiae }\end{array}$ & $\begin{array}{l}\text { Synthetic } \\
\text { solution }\end{array}$ & Probe & 27.5 & 0.16 & 10 & $\begin{array}{c}\text { Yeast cells suffer bactericidal } \\
\text { effects within early periods of sonication }\end{array}$ & Tsukamoto et al., 2004 \\
\hline \multirow[t]{2}{*}{ Total coliforms } & Well water & Probe & 22 & 2.4 & 15 & \multirow[t]{2}{*}{$\begin{array}{l}\text { Overall disinfection rate provided by the bath is } \\
\text { higher than the one provided by the horn. }\end{array}$} & \multirow[t]{2}{*}{$\begin{array}{l}\text { Jyoti and Pandit, } \\
2004 a\end{array}$} \\
\hline & & Bath & 20.5 & 0.06 & 15 & & \\
\hline $\begin{array}{l}\text { Gram- } \\
\text { positive/gram- } \\
\text { negative } \\
\text { bacteria }\end{array}$ & $\begin{array}{l}\text { Secondary } \\
\text { treated } \\
\text { municipal } \\
\text { wastewaters }\end{array}$ & Probe & 24 & 1.500 & 60 & $\begin{array}{l}\text { High removal efficiency for gram-negative bacteria } \\
\text { than for gram-positive }\end{array}$ & $\begin{array}{l}\text { Drakopoulou et al., } \\
\qquad 2009\end{array}$ \\
\hline
\end{tabular}


Table 2. Combination of ultrasound and other processes for microorganisms inactivation

\begin{tabular}{|c|c|c|c|c|c|c|c|}
\hline Microorganism & Aqueous mean & $\begin{array}{l}\text { Process/reagent combined } \\
\text { with US }\end{array}$ & $\begin{array}{l}\text { Ultrasonic } \\
\text { system }\end{array}$ & Frequency[kHz] & $\begin{array}{l}\text { Density } \\
{\left[\mathrm{W} \mathrm{I}^{-1}\right]}\end{array}$ & $\begin{array}{l}\text { Maximum sonication } \\
\text { time [min] }\end{array}$ & Reference \\
\hline \multirow{3}{*}{ Escherichia coli } & Synthetic solution & Sodium hypoclorite $\left(1 \mathrm{mg} \mathrm{l}^{-1}\right)$ & Bath & 20 and 850 & 6 & 5 & Duckhouse et al., 2004 \\
\hline & Synthetic solution & $\mathrm{TiO}_{2}$ photocatalyst & Bath & 39 & - & 30 & Dadjour et al., 2005 \\
\hline & WWTP effluent & UV-C (200 W/lamp) & Reactor & 39 & 5 & 30 & Naddeo et al., 2009c \\
\hline $\begin{array}{c}\text { Klebsiella } \\
\text { pneumonia }\end{array}$ & Synthetic solution & Electrolysis at $100 \mathrm{~mA}$ & Bath & 40 & 50 & 5 & Joyce et al., 2003b \\
\hline $\begin{array}{c}\text { Legionella } \\
\text { pneumophila }\end{array}$ & Synthetic solution & $\mathrm{TiO}_{2}$ photocatalyst $\left(0-1 \mathrm{~g} \mathrm{ml}^{-1}\right)$ & Bath & 36 & 50 & 30 & Dadjour et al., 2006 \\
\hline \multirow[b]{2}{*}{$\begin{array}{l}\text { Pseudomonas } \\
\text { aeruginosa }\end{array}$} & Water samples & $\mathrm{Cl}_{2}\left(\left.1 \mathrm{mg}\right|^{-1}\right)$ & Bath & 800 & 15000 & 20 & Phull et al., 1997 \\
\hline & $\begin{array}{c}\text { Secondary treated } \\
\text { municipal } \\
\text { wastewaters }\end{array}$ & $\mathrm{TiO}_{2}\left(5 \mathrm{mg} \mathrm{l}^{-1}\right)$ & Probe & 24 & 1500 & 30 & $\begin{array}{l}\text { Drakopoulou et al., } \\
2009\end{array}$ \\
\hline \multirow{7}{*}{ Total coliforms } & Well water & $\mathrm{H}_{2} \mathrm{O}_{2}$ & Bath & 20.5 & 2400 & 15 & Jyoti and Pandit, 2004a \\
\hline & Well water & $\mathrm{O}_{3}$ & Bath & 20.5 & 60 & 15 & Jyoti and Pandit, 2004b \\
\hline & \multirow{3}{*}{ Synthetic solution } & $\mathrm{TiO}_{2}\left(0.25-0.75 \mathrm{gl}^{-1}\right)$ & \multirow{3}{*}{ Probe } & \multirow{3}{*}{$24-80$} & \multirow{3}{*}{9000} & \multirow{3}{*}{30} & \multirow{3}{*}{ Paleologou et al., 2007} \\
\hline & & $\mathrm{Cl}_{2}\left(1-5 \mathrm{mg} \mathrm{I}^{-1}\right)$ & & & & & \\
\hline & & UV-A (9 W/lamp) & & & & & \\
\hline & WWTP effluent & UV-C (200 W/lamp) & Reactor & 39 & 5 & 30 & Naddeo et al., 2009c \\
\hline & $\begin{array}{c}\text { Secondary treated } \\
\text { municipal } \\
\text { wastewaters }\end{array}$ & $\mathrm{TiO}_{2}\left(5 \mathrm{mg} \mathrm{l}^{-1}\right)$ & Probe & 24 & 1500 & 30 & $\begin{array}{l}\text { Drakopoulou et al., } \\
2009\end{array}$ \\
\hline
\end{tabular}


After 10 min electrolysis $100 \%$ kill was achieved using all electrodes, with copper being the most efficient. When lowering the current from $150 \mathrm{~mA}$ to $100 \mathrm{~mA}$, the $40 \mathrm{kHz}$ ultrasound produced faster removal rates than the ones achieved with electrolysis alone at the higher current of $150 \mathrm{~mA}$.

This evidence suggests that the application of a combined US and electrolysis systems, under the optimal conditions, allows the reduction of energy inputs required to achieve comparable results by using the single technologies.

Schlager and Gorski, (2004), have recently patented a combined ultrasound and electrolytic disinfection apparatus that includes an electrolytic flow cell with electrodes forming a part of flow pipe or open channel through which water or wastewater passes. The electrodes are made of iron, stainless steel, carbon or copper. They are connected to a power supply voltage ranging between 20 and $100 \mathrm{~V}$, establishing a power supply in the range 1 - $6 \mathrm{~A}$. An ultrasonic transducer is connected to the electrodes and it enhances hydroxyl radical generation.

One of the most important aspects to be taken into account when electrolytic cells are employed is related to metal electrodes, which increase metal concentrations in solution, sometimes exceeding maximum contamination levels for silver, copper, lead or other metals. This represents one of the main disadvantages for the use of this technology in combination with US. Moreover, few papers on the topic are reported in literature, thus reducing the reliability of the combined process as well as the assessment of the economic feasibility.

\subsection{Ultrasound and $\mathrm{TiO}_{2}$ photocatalysist disinfection efficiency}

The addition of a catalyst such as $\mathrm{TiO}_{2}$ has been studied in order to reduce the ultrasonic energy input for disinfection purposes.

The combined process relies on the synergistic effect which occurs when ultrasonic energy is supplied to $\mathrm{TiO}_{2}$ particles. In these conditions, excited electrons move from the valence band to the conduction band and positive holes are generated in the valence band. Near the surface of $\mathrm{TiO}_{2}$ particles, holes react with water to generate more hydroxyl radicals (Cai et al., 1992), which provide an additional disinfection effect. When an ultrasonic wave is propagated via the solvent, all $\mathrm{TiO}_{2}$ particles are expected to contribute to the generation of radical species and the rate of disinfection would then be accelerated.

Several studies report the inactivation of $E$. coli, in the presence of $\mathrm{TiO}_{2}$ photocatalyst. Dadjour et al., (2005), used an ultrasonic bath at $39 \mathrm{kHz}$ and found that $98 \%$ reduction in the concentration of viable cells was achieved in presence of $\mathrm{TiO}_{2}$ during a 30 min period of irradiation. Only $13 \%$ reduction was observed when an ordinary ultrasonic irradiation system without $\mathrm{TiO}_{2}$ was used. Thus, $\mathrm{TiO}_{2}$ promotes the disinfection process by seven-fold under the investigated conditions. Authors stated that the effect of $\mathrm{TiO}_{2}$ was related to the heterogeneous nucleation of bubbles, which enhances the cavitation power. This, in turn, may increase the pyrolysis of $\mathrm{H}_{2} \mathrm{O}$ molecules and the formation of $\mathrm{OH}$ radicals, which are highly reactive and, therefore, short-lived. Moreover, $\mathrm{TiO}_{2}$ pellets stabilize reactive species, resulting in a more intensive oxidation (Dadjour et al., 2005).

Similar results were found on Legionella pneumophila. Dadjour et al., (2006), found that only $18 \%$ of the initial viable cells were killed after $30 \mathrm{~min}$ of treatment but the concentration of viable cells was reduced to $3 \%$ of the initial concentration in the presence of $1.0 \mathrm{~g} \mathrm{ml}^{-1} \mathrm{TiO}_{2}$ after a $30 \mathrm{~min}$ treatment period.

Other studies used the probe as US system in combination with $\mathrm{TiO}_{2}$. Drakopoulou et al., (2009), found that after 30 minutes sonication, $5.0 \mathrm{~g} \mathrm{I}^{-1} \mathrm{TiO}_{2}$ results in disinfection performances ranging between 37 and $99 \%$, according to the considered bacteria species. In particular, these authors stated that Gramnegative bacteria were more sensitive to sonication than Gram-positive ones.

Although the proposed method is capable of achieving disinfection standards for wastewater reuse, combined process optimization is still required to achieve the cost-effectiveness for large scale applications. 


\subsection{Ultrasound and ultraviolet disinfection efficiency}

Short-wave ultraviolet light (UV-C) is a radiation in the range $200-280 \mathrm{~nm}$ in the UV spectrum, whose germicidal effect on bacteria, virus, protozoa, fungi and algae (Unluturk et al., 2008) has been extensively investigated for disinfection purposes (Litved and Cripps, 1999; Sutton et al., 2000).

Several studies evaluated the effectiveness of ultrasound application as a pre-treatment step in combination with ultraviolet rays to optimize wastewater disinfection process (Blume and Neis, 2003).

Paleologou et al., (2007), examined this combined system and compared it with various other combinations of both ultrasound and UV radiation with $\mathrm{TiO}_{2}$ photocatalysis. Authors found that US allowed the halving of the reaction time necessary to obtain complete removal of Total coliforms by UV radiation alone.

Naddeo et al. (2009c) investigated the combined ultrasound and ultraviolet disinfection process in a pilot-scale configuration which is schematically shown in Figure 3.

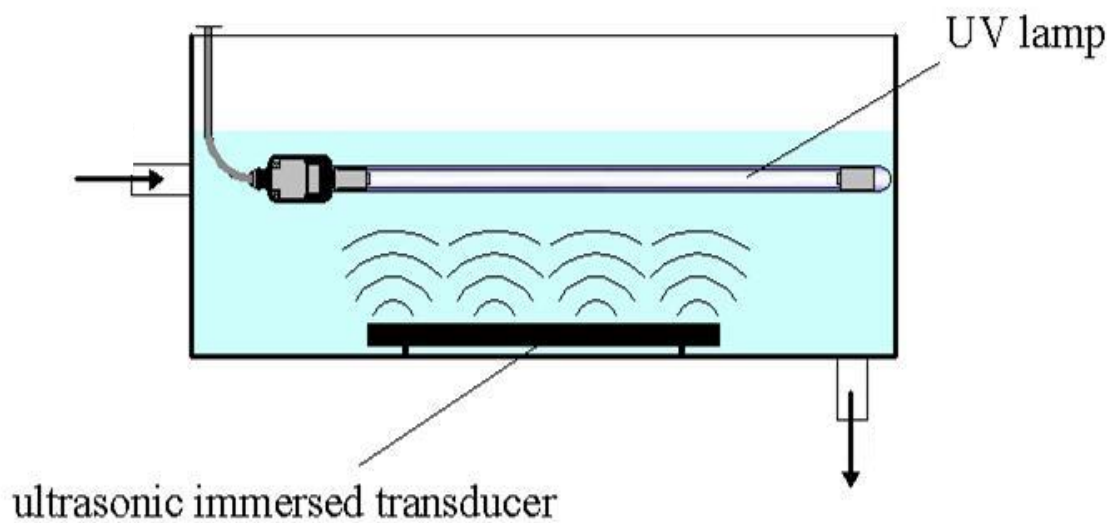

Figure 3. Experimental setup for combined ultrasound and ultraviolet disinfection (Adapted from Naddeo et al., 2009c)

The reactor consists of a low frequency $(39 \mathrm{kHz})$ ultrasonic transducer capable of operating at ultrasound power varying between 350 and $1400 \mathrm{~W}$ and two low pressure UV-C lamps of $150 \mathrm{~W}$ each. The treated volume was $80 \mathrm{~L}$. Experimental tests showed that UV disinfection efficiency was enhanced in presence of US, especially when treating wastewater with low transmittance.

After approximately $55 \mathrm{~h}$ of continuous treatment, the disinfectant power was still up to $90 \%$ in the combined ultrasound/UV reactor, whereas in the UV reactor, the inactivation went down until $77 \%$. This evidence was related to the influence of US on the formation of fouling on the lamps.

During the tests, lamps in UV reactor became dirtier and dirtier; in presence of US, UV lamps were perfectly clean, even after three days of treatment. The US cleaning effects was provided by the collapse of cavitation bubbles, which produced liquid jets on the surface of lamps. In this way, ultrasound broke the cake layer on the lamps making the UV beans emission achievable in wastewater.

The combined US/UV-C system has been recently studied for elimination of pathogens in recirculating aquaculture systems (Bazyar Lakeh et al., 2013). To this end, dose-dependent inactivation rates were determined for the total viable counts and model organisms representing different taxa of common fish parasites. Authors found that a pre-treatment with low frequency ultrasound reduced the mean size of suspended solids in aquaculture water, thus increasing the germicidal effect of UV-C by up to $0.6 \log$ units.

The innovative aspect of this recent investigation lays in the coupling of UV systems, which are commonly used for the prevention of bacterial, viral and fungal diseases in aquaculture facilities, with low frequency US that had not been studied yet in the aquaculture field. 
The effectiveness of coupled UV-C and US process lays in the possibility of improving disinfection yields of the former by using the latter to reduce dissolved organic matter and suspended solid, which are recognized to provide significant interferences to UV irradiation.

In this way, UV reaction time can be conveniently shortened to ensure disinfection targets. The reduction of reaction time would result in the decrease of working volumes, with the consequent reduction in capital costs. Moreover, the positive influence of US on lamp fouling would reduce maintenance costs. Despite these advantages, US/UV process cost-effectiveness should take into account the energy requirements during the simultaneous operation of the combined system. Further studies are, therefore, necessary to assess energy balances as well as to evaluate the competitiveness of this system with other integrated processes.

\subsection{Ultrasound and ozone disinfection efficiency}

The use of ultrasound in combination with ozone, which is a powerful oxidant, enhances water and wastewater treatment by producing an emulsion from both suspended particles and dispersed microorganisms as well as by preventing the coalescence of ozone bubbles, ensuring that maximum bubble surface area is available for oxidation (Burleson et al., 1975).

One of the first studies was performed by using a pilot plant processing $76 \mathrm{~m}^{3} \mathrm{~d}^{-1}$ of sewage: it was found that $1 \mathrm{~min}$ of treatment with both ultrasound and ozone destroyed $100 \%$ of faecal bacteria and viruses (Chendke and Fogler, 1975).

Jyoti and Pandit, (2004a), also examined the application of acoustic cavitation and ozonation for the disinfection of water. Their lab-scale work was carried out with an ultrasonic horn operating at $22 \mathrm{kHz}$ frequency and $240 \mathrm{~W}$ electrical power. They also used an ultrasonic bath $(145 \times 145 \times 150 \mathrm{~mm})$ characterized by a peak operative frequency of $20.5 \mathrm{kHz}$ and an electrical power consumption of $120 \mathrm{~W}$. After 15 min sonication, $100 \%$ efficiency in removing Total coliforms was achieved.

The same authors studied the coupling of ozone and US for the inactivation of Total coliforms, Faecal coliforms and Faecal streptococci in bore well water (2004b). In their investigation, ozone was supplied by a generator according to the corona discharge method. A dry air flow rate of $28 \mathrm{I} \mathrm{s}^{-1}$ was used as the feed gas. Sonication was applied through the same devices used in the previously mentioned investigation (Joyti and Pandit, 2004b). It was found that by using the combination of ultrasonic horn and ozone or hydrodynamic cavitation and ozone, the concentration of ozone required for disinfection was reduced to half or one-third depending upon the type of microorganism.

Although both ozone and ultrasound are effective technologies for water and wastewater disinfection, main disadvantages are related respectively to the high costs for ozone production and to the great energy consumption for ultrasound generation. However, their combination can allow the reduction of both ozone doses and ultrasound energy, with the consequent reduction of operating costs.

A further advantage from the coupling of ozone and US for disinfection purposes and, as a consequence, from the decrease of ozone doses is the elimination of toxic by-products associated to ozonation reactions and, in particular, to the oxidation of natural organic matter (NOM) or halogen compounds (von Gunten, 2003).

The assessment of the cost-effectiveness of the combined US/O $\mathrm{O}_{3}$ disinfection process requires further studies dealing with operating condition optimization, as already pointed out for the combined US/UV process. However, in this case, the high costs associated with ozone generation at full scale would represent a limit for the spread of the combined process, especially if compared with the coupling of US with other chemical processes.

\subsection{Ultrasound and chemicals disinfection efficiency}

A further option for water and wastewater disinfection is the application of ultrasound in combination with chemicals. 
The effects of low $(20 \mathrm{kHz})$ and high $(850 \mathrm{kHz})$ frequency ultrasound on the biocidal efficiency of sodium hypochlorite against $E$. coli suspensions were studied by Duckhouse et al., (2004). Operating at the lower frequency and a power intensity of $17 \mathrm{~W} \mathrm{~cm}^{-2}$, maximum inactivation was achieved when ultrasound irradiation and hypochlorite were applied simultaneously to the suspension. Conversely, at the higher frequency of $850 \mathrm{kHz}$ and a power intensity of $0.03 \mathrm{~W} \mathrm{~cm}^{-2}$, efficiency was optimized when ultrasound was used as a pre-treatment immediately followed by hypochlorite addition under silent conditions. In particular, pre-treatment using $850 \mathrm{kHz}$ proved to be very effective at 1 min exposure with an increase of kill by about 2-log reduction in comparison with the control experiment. On the other hand, pre-treatment at $20 \mathrm{kHz}$ had a small adverse effect on the rate of kill of chlorine at all exposure times up to 5 min pre-treatment, while simultaneous application of hypochlorite and ultrasound resulted in almost a 2-log reduction in kill at either 1 or 5 min exposure.

Coupled ultrasound and chlorine treatment was applied for water disinfection in the study of Phull et al., (1997). The experimental work was performed using both a probe and a bath on previously chlorinated samples. Authors observed that sonication amplified the effect of normal chlorination, thus promoting the reduction of the amount of chlorine required for disinfection.

Finally, Joyti and Pandit (2004a) investigated the effects of a combined US/ $\mathrm{H}_{2} \mathrm{O}_{2}$ process on bacteria inactivation. To this end, for the experiments involving the HPC bacteria, $150 \mathrm{mg} \mathrm{l}^{-1} \mathrm{H}_{2} \mathrm{O}_{2}$ was used and for the indicator microorganisms ( $T$. coliforms, F. coliforms and $F$. streptococci) $5 \mathrm{mg} \mathrm{l}^{-1} \mathrm{H}_{2} \mathrm{O}_{2}$ was used. This dosage was added to bore well water before subjecting it to ultrasonication. It was observed that the disinfection efficiency of acoustic cavitation was increased when hydrogen peroxide was added, with higher specific extent of disinfection for the combination of $5 \mathrm{mg} \mathrm{I}^{-1}$ of hydrogen peroxide with the ultrasonic bath rather than horn.

Similar results were obtained for wastewaters.

Ultrasound and chlorine dioxide were combined sequentially to improve Escherichia coli and Total coliform inactivation in raw wastewater (Ayyildiz et al., 2011). A sequential application of ultrasonic density values of 150 or $300 \mathrm{~W} \mathrm{I}^{-1}$ and a $\mathrm{ClO}_{2}$ concentration of $2 \mathrm{mg} \mathrm{l}^{-1}$ provided about 3.2-3.5 log reduction in the number of microorganisms, while the sum of log reductions by the individual treatments were 1.4-1.9. This enhancement was attributed to the presence of high concentration of particles in raw wastewater and their influence in improving ultrasonic cavitation effects.

The comparison of those works highlighted the fundamental role played by the matrix under investigation and the need for studies on real wastewater. Although the use of synthetic solutions can promote the identification of disinfection mechanisms as well as the evaluation of specific aspects by eliminating interferences related to the presence of different substances, experimental results acquire a further reliability when validated under conditions as near as possible to the real ones.

Although treatment conditions are quite different in the reviewed studies, it can be concluded that short sonication times allow the decrease of chemical disinfectant amount. This item results in the reduction of operating costs associated with reagent supply and points out that US could be an interesting option for the upgrade of conventional chlorination systems.

Moreover, sonication times are even shorter than the ones applied in combination with $\mathrm{TiO}_{2}$ addition or UV irradiation, suggesting that the combined US/chemical disinfectant process could be more competitive.

\section{LIMITS AND POTENTIAL OF ULTRASOUND TECHNOLOGY}

The use of ultrasound has been extensively studied for disinfection purposes, even in combination with other systems, so that main potentialities and limits can be highlighted.

Table 3 summarises main advantages and disadvantages of ultrasound induced disinfection systems.

As pointed out in previous paragraphs, ultrasound process can determine the removal of different kind of pathogens from both water and wastewater and inactivation yields are usually high and quite close to 
the complete removal, notwithstanding the kind of microorganism under investigation. This evidence can be related to the action mechanism of ultrasound, whose effects are mainly produced by the mechanical disintegration of bacteria cell, especially when operating in the field of low frequencies. Moreover, it has been recognized that US is also effective in the degradation of chemical pollutants, so that not only disinfection but also an improvement of the process effluent can be achieved. This item is even more interesting if the generation of disinfection by-products is considered: differently from other conventional systems, such as chlorination or ozonation, ultrasound does not provide the formation of toxic compounds, potentially harmful for human health.

Table 3. Advantages and disadvantages of ultrasound-induced disinfection systems

\begin{tabular}{ll}
\hline Advantages & Disadvantages \\
\hline Simple, flexible design with low capital costs & Design criteria still developing \\
\hline Easy upgrading of conventional treatment unit & Increase of water turbidity \\
\hline High efficiency of several bacteria inactivation & Energy consumption \\
\hline $\begin{array}{l}\text { Oxidation of natural organic matter and degradation of } \\
\text { chemicals pollutants }\end{array}$ & $\begin{array}{l}\text { Maintenance/replacement of } \\
\text { ultrasound probe }\end{array}$ \\
\hline $\begin{array}{l}\text { No production of conventional disinfection by-products (THMs, } \\
\text { etc.) }\end{array}$ & $\begin{array}{l}\text { Lack of remaining disinfection } \\
\text { capacity }\end{array}$ \\
\hline
\end{tabular}

High synergy/improved efficiency in combination with

conventional disinfection treatments $\left(\mathrm{O}_{3} ; \mathrm{Cl}_{2} ; \mathrm{UV}\right)$.

On the other hand, the turbidity increase should be highlighted as one of the main disadvantages of US application, along with the lack of a remaining disinfection capacity.

Under an operational point of view, ultrasonic reactors are compact and flexible, often commercialized as modular units, so that their implementation for the upgrade of existing disinfection units can be considered. In this case, the high synergy with conventional disinfection treatments ensures the achievement of high pathogen removal yields.

It should be pointed out that, up to now, the design features of most devices have been developed following empirical data: theoretical criteria are still being developed in order to rationalise the design of these systems as well as their application to larger volumes.

From an economic point of view, despite a relatively low capital cost, ultrasound allows the economic treatment only for small volumes, mainly due to the high energy consumption associated to ultrasound generation. Further operating costs are related to the maintenance and/or replacement of the devices, which tend to be eroded by the ultrasonic action itself.

\section{CONCLUSIONS}

In recent years the increasingly restrictive limits for water and wastewater disinfection has addressed the research towards the study of innovative methods to ensure high yields in pathogenic bacteria removal. The ultrasound process, even in combination with traditional disinfection methods, showed interesting results that were summarised in this work.

This review showed that for both Escherichia Coli and Total Coliform the best results in water disinfection were obtained through the use of ultrasound treatments with low frequencies $(20-40 \mathrm{kHz})$, medium-low power $(<120 \mathrm{~W})$, high density and sonication times varying between 3 to $15 \mathrm{~min}$.

Similar treatment conditions can determine bacteria inactivation usually greater than $90 \%$, notwithstanding the kind of microorganism under investigation. However, some species of bacteria, which can agglomerate into clusters thus proving to be resistant to conventional disinfection methods, were removed more easily by means of ultrasonic processes. 
Literature data also pointed out that sonolysis efficiency in bacteria inactivation can be further increased by coupling this technology with other oxidative systems. As an additional advantage, this condition is often obtained with a significant reduction in reaction time. Pilot scale experiments proved that only 1 minute of treatment by means of ozonation and sonolysis allowed $100 \%$ microorganism inactivation.

On the basis of literature review, further studies should be addressed towards the definition of relations between disinfection yields and main parameters affecting process efficiency, such as contact time, radiated power and reactor features. The in-depth analysis of these aspects could also support the study of theoretical models able to describe the acoustic cavitation field provided by US, even in combination with other processes, as well as to predict the effects of specific treatment conditions on different kinds of matrix to be disinfected.

The analysis of scientific literature shows that most studies were performed using synthetic wastewater. The civil wastewater use is an essential factor for the reliable estimation of disinfection process efficiency, as it allows the investigation of conditions close to the real ones, thus paving the way for process scale-up considerations.

Experimental results are certainly encouraging, even with reference to possible reuse of investigated aqueous matrixes, ensuring high pathogenic removal yields without the risk of formation of toxic byproducts, such as trihalomethanes (THMs). Further benefits from US disinfection treatment are related to: the guarantee of high efficiency bactericide for various viral and bacterial species, even with reference to those chlorine-resistant; the high oxidant power which can reduce concentrations of organic matter and many toxic compounds, such as pharmaceuticals, usually found in wastewater; the possibility of applying this technology for the upgrade of existing plants. Conversely, the disadvantages are primarily associated with increasing turbidity, which is generated by long delays contact times, high density and transducers wear.

In the perspective of real scale applications of ultrasound disinfection treatments, a fundamental aspect to be better clarified is the possible formation of harmful by-products: to this end, toxicological analyses are required.

Finally, the feasibility of this technology full-scale needs to be assessed. More studies should, therefore, be carried out in order to establish energy consumption levels, in order to verify the technical and economic competitiveness of ultrasound towards conventional technologies.

\section{References}

Antoniadis A., Poulios I., Nikolakaki E. and Mantzavinos D. (2007), Sonochemical disinfection of municipal wastewater, Journal of Hazardous Materials, 146, 492-495.

Arrojo S., Benito Y. and Martínez Tariffa A. (2008), A parametrical study of disinfection with hydrodynamic cavitation, Ultrasonics Sonochemistry, 15, 903-908.

Asher R.C. (1987), Ultrasonics in chemical analysis, Ultrasonics, 25, 17-19.

Ayyildiz O., Sanik S. and Ileri B. (2011), Effect of ultrasonic pretreatment on chlorine dioxide disinfection efficiency, Ultrasonics Sonochemistry, 18, 683-688.

Bazyar Lakeh A.A., Kloas W., Jung R., Ariav R. and Knopf K. (2013), Low frequency ultrasound and UV-C for elimination of pathogens in recirculating aquaculture systems, Ultrasonics Sonochemistry, 20, 1211-1216.

Belgiorno V., Rizzo L., Fatta D., Della Rocca C., Lofrano G., Nikolaou A., Naddeo V. and Meric S. (2007), Review on endocrine disrupting-emerging compounds in urban wastewater: occurrence and removal by photocatalysis and ultrasonic irradiation for wastewater reuse, Desalination, 215, 166-176.

Blume T. and Neis U. (2004), Improved wastewater disinfection by ultrasonic pre-treatment, Ultrasonic Sonochemistry, 11, 333-336.

Bonacquisti T.P. (2006), A drinking water utility's perspective on bromide, bromate, and ozonation, Toxicology, 221, 145-148.

Bougrier C., Carrere H. and Delgenes J.P. (2005), Solubilisation of waste activated sludge by ultrasonic treatment, Chemical Engineering Journal, 106, 163-169. 
Brown B. and Goodman J.E. (1965), High Intensity Ultrasonics, lliffe Books Ltd, London.

Burgos J., Ordonaez J.A. and Sala F. (1972), Effect of ultrasonic waves on the heat resistance of Bacillus Cerus and Bacillus Licheniforms spores, Applied Microbiology, 24, 497-498.

Burleson G.R., Murray T.M. and Pollard M. (1975), Inactivation of viruses and bacteria by ozone, with and without sonication, Applied Microbiology, 29, 340-344.

Byrne S.F. (1984), Standardized echography in the differentiation of orbital lesions, Survey of Ophthalmology, 29, 226-228.

Cai R., Kubota Y., Shuin T., Sakai H., Hashimoto K. and Fujishima A. (1992), Induction of cytotoxicity by photoexcited $\mathrm{TiO}_{2}$ particles, Cancer Research, 52, 2346-2348.

Carrére H., Dumas C., Battimelli A., Batstone D.J., Delgenès J.P., Steyer J.P. and Ferrer I. (2010), Pretreatment methods to improve sludge anaerobic degradability: a review, Journal of Hazardous Materials, 183, 1-15.

Cesaro A., Naddeo V., Amodio V. and Belgiorno V. (2012), Enhanced biogas production from anaerobic codigestion of solid waste by sonolysis, Ultrasonics Sonochemistry, 19, 596-600.

Cesaro A. and Belgiorno V. (2013), Sonolysis and ozonation as pretreatment for anaerobic digestion of solid organic waste, Ultrasonics Sonochemistry, 20, 931-936.

Cesaro A., Velten S., Belgiorno V. and Kuchta K. (2014), Enhanced anaerobic digestion by ultrasonic pretreatment of organic residues for energy production, Journal of Cleaner Production, http://dx.doi.org/10.1016/j.jclepro.2014.03.030 (In press).

Chen L., Li B., Li D., Gan J. and Kitamura Y. (2008), Ultrasound-assisted hydrolysis and acidogenesis of solid organic wastes in a rotational drum fermentation system, Bioresource Technology, 99, 8337-8343.

Chendke P. K. and Fogler H. S. (1975), Macrosonics in industry, Ultrasonics, 13, 31-37.

Chu C.P. and Lee D.J. (2004), Effect of pre-hydrolysis on floc structure, Journal of Environmental Management, 71, 285-292.

Climent M., Ferrer I., Del Mar Baeza M., Artola A., Vàzquez F. and Font X. (2007), Effects of thermal and mechanical pretreatments of secondary sludge on biogas production under thermophilic conditions, Chemical Engineering Journal, 133, 335-342.

Collasiol A., Pezebon D. and Maia S.M. (2004), Ultrasound assisted mercury extraction from soil and sediment, Analytica Chimica Acta, 518, 157-164.

Dadjour M.F., Ogino C., Matsumura S. and Shimizu N. (2005), Kinetics of disinfection of Escherichia coli by catalytic ultrasonic irradiation with $\mathrm{TiO}_{2}$, Biochemical Engineering Journal, 25, 243-248.

Dadjour M.F., Ogino C., Matsumura S., Nakamura S. and Shimizu N. (2006), Disinfection of Legionella pneumophila by ultrasonic treatment with $\mathrm{TiO}_{2}$, Water Research, 40, 1137-1142.

Dahl E. (1976), Physicochemical aspects of disinfection of water by means of ultrasound and ozone, Water Research, 10, 677-684.

Dehghani M.H. (2005), Effectiveness of Ultrasound on the Destruction of E. Coli, American Journal of Environmental Science, 1, 187-189.

Drakopoulou S., Terzakis S., Fountoulakis M.S., Mantzavinos D. and Manios T. (2009), Ultrasound-induced inactivation of gram-negative and gram-positive bacteria in secondary treated municipal wastewater, Ultrasonics Sonochemistry,16, 629-634.

Duckhouse H., Phull S.S., Mason T.J. and Lorimer J.P. (2004), The effect of sonication on microbial disinfection using hypochlorite, Ultrasonics Sonochemistry, 11, 173-176.

Dunn F. (1991), Ultrasound, IEEE Transactions on Education, 34, 266-268.

El' Piner I.E. (1964), Ultrasound, physical, chemical and biological effects, Consultants Bureau: New York.

Fernández P., Blanco J., Sichel C., Malato S. (2005), Water disinfection by solar photocatalysis using compound parabolic collectors, Catalysis Today, 101, 345-352.

Flisak F. and Perna A. (1977), The influence of ultrasonics on liquid-liquid extraction, Ultrasonics, 15, 27-29.

Floros J.D. and Liang H. (1994), Acoustically assisted diffusion through membranes and biomaterials, Food Technology, 48, 79-84. 
Furuta M., Yamaguchi M., Tsukamoto T., Yim B., Stavarache C.E., Hasiba K. and Maeda Y. (2004), Inactivation of Escherichia coli by Ultrasonic irradiation. Ultrasonics Sonochemistry, 11, 57-60.

Gogate P.R. and Pandit A.B. (2004), Sonochemical reactors: scale up aspects. Ultrasonics Sonochemistry, 11, 105-117.

Gogate P. (2007), Application of cavitational reactors for water disinfection: Current status and path forward, Journal of Environmental Management, 85, 801-815.

Gogate P.R. (2008), Treatment of wastewater streams containing phenolic compounds using hybrid techniques based on cavitation: A review of the current status and the way forward, Ultrasonics Sonochemistry, 15, 1-15.

Gonze E., Commenges N., Gonthier Y. and Bernis A. (2003), High frequency ultrasound as a pre- or a post-oxidation for paper mill wastewaters and landfill leachate treatment, Chemical Engineering Journal, 92, 215-225.

Gopal K., Tripathy S.S., Bersillon J.L. and Dubey S.P. (2007), Chlorination byproducts, theri toxicodynamics and removal from drinking water, Journal of Hazardous Materials, 140, 1-6.

Grinthal W. and Ondrey G. (1992), Ultrasound seen but not heard, Chemical Engineering Journal, 99, 37-41.

Harvey E.N. and Loomis A.L. (1929), The destruction of luminous bacteria by high frequency sound waves, Journal of Bacteriology, 17, 373-379.

Hoffmann M.R., Hua I. and Hochemer R. (1996), Application of ultrasound irradiation for the degradation of chemical contaminants in water, Ultrasonics Sonochemistry, 3, S163-S172.

Hoyler B.S. and Luke S.P. (1994), Ultrasound in the process industries, Engineering, Science and Education Journal, 3, 119-122.

Hua I. and Thompson J.E. (2000), Inactivation of Escherichia coli by Sonication at discete ultrasonic frequencies. Water Research, 34(15), 3888-3893.

Hunicke R.L. (1990), Industrial applications of high power ultrasound for chemical reactions, Ultrasonics, 28, 291-294

Ince N.H., Tezcanli G., Belen R.K. and Apikyan Pi.G. (2001), Ultrasound as a catalyzer of aqueous reaction systems: the state of the art and environmental applications, Applied Catalysis B: Environmental, 29, 167-176.

Joyce E., Phull S.S., Lorimer J.P., Mason T.J. (2003a), The development and evaluation of ultrasound for the treatment of bacterial suspensions. A study of frequency, power and sonication time on cultured Bacillus species, Ultrasonics Sonochemistry, 10, 315-318.

Joyce E., Phull S.S., Lorimer J.P., Mason T.J. (2003b), The development and evaluation of electrolysis in conjunction with power ultrasound for the disinfection of bacterial suspensions, Ultrasonics Sonochemistry, 10, 231-234.

Jyoti K.K. and Pandit A.B. (2004a), Effect of cavitation on chemical disinfection efficiency, Water Research, 18, 9-19.

Jyoti K.K. and Pandit A.B. (2004b), Ozone and cavitation for water disinfection, Biochemical Engineering Journal, 38, 2249-2258.

Khan E., Shen C. and Lin H. (2006), Use of Low-Frequency Sonication for the Production of Biodegradable Dissolved Organic Carbon in Water, Environmental Engineering Science, 23(2), 367-371.

Kulier R. and Kapp N. (2011), Comprehensive analysis of the use of preprocedure ultrasound for first- and secondtrimester abortion, Contraception, 83, 30-33.

Lema J.M., Mendez R. and Blazquez R. (1998), Characteristics of landfill leachates and alternatives for their treatment: a review, Water Air Soil Pollution, 40, 223-250.

Lifka J., Ondruschka B. and Hofmann J. (2003), The use of ultrasound for the degradation of pollutants in water: aquasonolysis - a review, Engineering Life Science, 3, 253-262.

Lin L.S., Johnston C.T. and Blatchley E.R. (1999), Inorganic fouling at quartz: water interfaces in ultraviolet photoreactors-II. Temporal and spatial distributions, Water Research, 33, 3330-3338.

Litved H. and Cripps S.J. (1999), Removal of particle-associated bacteria by prefiltration and ultraviolet irradiation, Aquaculture Research, 30, 445-450.

Mason W.P. (1976), Sonics and ultrasonics: early history and applications, IEEE Transactions on Sonics and Ultrasonics, SU-23(4), 224-232.

Mason T.J. and Tiehm A. (2001), Advances in Sonochemistry, Volume 6: Ultrasound in Environmental Protection, Elsevier, Amsterdam, The Netherlands. 
Mason T.J. and Peters D. (2002), Practical Sonochemistry: Power Ultrasound and Applications, Second Edition, Horwood, Chichester, England.

Mason T.J., Joyce E., Phull S.S. and Lorimer J.P. (2003), Potential uses of ultrasound in the biological decontamination of water, Ultrasonics Sonochemistry, 10, 319-323.

Mason T.J. (2007), Developments in ultrasound-Non-medical. Progress in Byophisics \& Molecular Biology, 93, 166175

Mecozzi M., Amici M., Pietrantonio E. and Romanelli G. (2002), An ultrasound assisted extraction of the available humic substance from marine sediments, Ultrasonics Sonochemistry, 9, 11-18.

Méndez-Arriaga F., Torres-Palma R.A., Pétrier C., Esplugas S., Gimenez J. and Pulgarin C. (2008), Ultrasonic treatment of water contaminated with ibuprofen, Water Research, 42, 4243-4248.

Moreda-Piñeiro A., Bermejo-Barrera A. and Bermejo-Barrera P. (2004), New trends involving the use of ultrasound energy for the extraction of humic substances from marine sediments, Analytica Chimica Acta, 524, 97-107.

Naddeo V., Belgiorno V. and Napoli R.M.A. (2007), Behaviour of natural organic matter during ultrasonic irradiation, Desalination, 10, 175-182.

Naddeo V., Belgiorno V., Ricco D. and Kassinos D. (2009a), Degradation of diclofenac by sonolysis, ozonation and their simultaneous application, Ultrasonics. Sonochemistry, 16, 790-794.

Naddeo V., Meric S., Kassinos D., Belgiorno V. and Guida M. (2009b), Fate of pharmaceuticals in contaminated urban wastewater effluent under ultrasonic irradiation. Water Research, 43, 4019-4027.

Naddeo V., Landi M., Belgiorno V. and R.M.A. Napoli (2009c), Wastewater disinfection by combination of ultrasound and ultraviolet irradiation, Journal of Hazardous Materials, 168, 925-92.

Naddeo V., Belgiorno V., Landi M., Zarra T. and Napoli R.M.A. (2009d), Effect of sonolysis on waste activated sludge solubilisation and anaerobic biodegradability, Ultrasonics Sonochemistry, 249, 762-767.

Naddeo V., Belgiorno V., Kassinos D., Mantzavinos D. and Meric S. (2010), Ultrasonic degradation, mineralization and detoxification of diclofenac in water: Optimization of operating parameters, Ultrasonics Sonochemistry, 17, 179-185.

Neczaj E., Kacprzak M., Lach J. and Okoniewska E. (2007), Effect of sonication on combined treatment of landfill leachate and domestic sewage in SBR reactor, Desalination, 204, 227-233.

Neppiras E.A. (1980), Acoustic Cavitation, Physical Report, 61, 159-251.

Oyane I., Takeda T., Oda Y., Sakata T., Furuta M., Okitsu K., Maeda Y. and Nishimura R. (2009), Comparison between the effects of ultrasound and gamma-rays on the inactivation of Saccharomyces cerevisiae: analyses of cell membrane permeability and DNA or RNA synthesis by flow cytometry, Ultrasonics Sonochemistry, 16, 532-536.

Paleologou A., Marakas H., Xekoukoulotakis N. P., Moya A., Vergara Y., Kalogerakis N., Gikas P. and Mantzavinos D. (2007), Disinfection of water and wastewater by $\mathrm{TiO}_{2}$ photocatalysis, sonolysis and UV-C irradiation, Catalysis Today, 129, 136-142

Phull S.S., Newman A.P., Lorimer J.P., Pollet B. and Mason T.J. (1997), The development and evaluation of ultrasound in the biocidal treatment of water, Ultrasonics Sonochemistry, 4, 157-164.

Reisse J., Francois H., Vandercammen J., Fabre O., Kirsch-De Mesmaeker A., Maerschalk C. And Delplancke J.L. (1999), Sonoelectrochemistry in aqueous electrolyte: a new type of sonoelectroreactor, Electrochimica Acta, 39, 37-39.

Rice R.G., Evison L.M. and Robson C.M. (1981), Ozone disinfection of municipal wastewater-current state of the art, Ozone Science and Engineering, 3, 239-272.

Richards W.T. and Loomis A.L. (1927), The chemical effects of high frequency sound waves. A preliminary survey, Journal of the American Chemical Society, 49, 3086-3100.

Rook J.J. (1974), Formation of haloforms during chlorination of natural waters, Society for water treatment and examination, 23, 234-243.

Sadiq R. and Rodrssiguez M.J. (2004), Disinfection byproducts (DBPs) in drinking water and predictive models for their occurrence: a review, Science of the Total Environment, 321, 21-46.

Schlager K.J. and Gorski S.H. (2004), Electronic water disinfection apparatus. US Patents N 6780306. 
Secondes M.F.N., Naddeo V., Belgiorno V. and Ballesteros F. jr (2014), Removal of emerging contaminants by simultaneous application of membrane ultrafiltration, activated carbon adsorption and ultrasound irradiation, journal of Hazardous Materials, 264, 342-349.

Serpone N., Terzian R., Hidaka H. and Pelizzetti E. (1994), Ultrasonic induced dehalogenation and oxidation of 2-, 3and 4-chlorophenol in air-equilibrated aqueous media. Similarities with irradiated semiconductor particulates, Journal of Physical Chemistry, 98, 2634-2640.

Srinivasan R., Shirgaonkar I.Z. and Pandit A.B. (1995), Effect of sonication on crystal properties, Separation Science and Technology, 30, 2239-2243.

Suslick K.S., Doktycz S.J. and Flint E.B. (1990), On the origin of sonoluminescence and sonochemistry, Ultrasonics, 28, 280-290.

Sutton J.C., Yu H., Grodzinski B., Johnstone M. (2000), Relationships of ultraviolet irradiation dose of inactivation of pathogen propagules in water and hydroponic nutrient solutions, Canadian Journal of Plant Pathology, 22, 300-309.

Symons J.M., Prengle J.W. and Belhateche D. (1989), Use of ultraviolet irradiation and hydrogen peroxide for the control of solvent contamination in small water utilities, Journal of Hazardous Materials, 22, 265-266.

Thakore K.A. (1990), Physico-chemical study on applying ultrasonics in textile dyeing. Part I, American Dyest Report, 79, 45-47.

Thomas J.R. and De Vries L. (1959), Sonically induced heterolytic cleavage of polymethylsiloxane, Journal of Physical Chemistry, 63, 254-256

Tiehm A., Nickel K. and Neis U. (1997), The use of ultrasound to accelerate the anaerobic digestion of sewage sludge, Water Science and Technology, 36, 121-128.

Tsukamoto I., Yim B., Stavarache C.E., Furuta M., Hashiba K. and Maeda Y. (2004), Inactivation of Saccharomyces cerevisiae by ultrasonic irradiation, Ultrasonics Sonochemistry, 11, 61-65.

Unluturk S., Atilgan M., Handan Baysal A. and Tari C. (2008), Use of UV-C radiation as a non-thermal process for liquid egg products (LEP), Journal of Food Engineering, 85, 561-568.

von Gunten U. (2003), Ozonation of drinking water: Part II. Disinfection and by-product formation in presence of bromide, iodide and chlorine, Water Research, 37, 1469-1487.

von Sonntag C. (1986), Disinfection by free-radicals and UV-radiation, Water Supply, 4, 9-10.

Wait I.W., Johnston C.T. and Blatchley E.R. (2007), The influence of oxidation reduction potential and water treatment processes on quartz lamp sleeve fouling in ultraviolet disinfection reactors, Water Research, 41, 2427-2436.

Wang F., Wang Y. and Ji M. (2005), Mechanisms and kinetics models for ultrasonic waste activated sludge disintegration, Journal of Hazardous Materials, B123, 145-150.

Winward G.P., Avery L.M., Stephenson T. and Jefferson B. (2008), Chlorine disinfection of grey water for reuse: Effect of organics and particles, Water Research, 42, 483-491. 